\title{
Variations of Incidence, Types of Virus Diseases and Insect Vector Populations of Tomato (Solanum lycopersicum L.), Grown in Different Agro- ecological Regions of Sri Lanka under Two Crop Management Systems
}

\author{
K. Prasannath ${ }^{*}$, K.N.P. Dharmadasa, D.M. De Costa $^{1}$ and K.S. Hemachandra ${ }^{1}$ \\ Postgraduate Institute of Agriculture \\ University of Peradeniya \\ Sri Lanka
}

\begin{abstract}
Incidence and types of insect-transmitted virus diseases of plants vary with the environmental factors, which have direct or indirect relationships on population dynamics of vectors. Alternative indirect strategies are essential to mitigate the environmental and health hazards of pesticide usage, which is the most predominant method of vector management used at present. The present study was conducted to determine the variation of virus disease incidence and the population of insect vectors in field grown tomato (Solanum lycopersicum L.) cv. Thilina in different environmental conditions using two crop management systems namely, existing management system with pesticide applications and an integrated management package (IMP) with less reliance on pesticides. Incidence and types of virus diseases, their abundance and types of both insect vectors and beneficial insects were recorded over one cropping season, together with mean day temperature and rainfall data. Peroxidase activity in tomato tissues was quantified spectrophotometrically to determine the effects of the location and management practices on build-up of defence related enzymes in plant tissues. Relationships between the virus disease incidence, vector and beneficial insect populations and climatic parameters were also analyzed. Results revealed that there was no significant $(p=0.05)$ difference between the two types of management systems in terms of virus disease incidence indicating the equal efficiency of the tested IMP treatment and existing pest control method on virus disease management. Abundance of insect vectors and beneficial insect populations were significantly $(p<0.05)$ influenced by the interaction effect of the management system and location. The mean day temperature was weakly related with the virus disease incidence at different locations. Peroxidase activity of tomato tissues was significantly $(p<0.05)$ different among locations and did not significantly vary between the plants treated with IMP and the existing management systems.
\end{abstract}

Keywords: Integrated management package, peroxidase activity, tomato, virus diseases, virus vectors

\section{INTRODUCTION}

Tomato (Solanum lycopersicum L.) is one of the popular vegetables grown across a wide range of agroecological regions of Sri Lanka. However, the average productivity of tomato under Sri Lankan conditions $\left(11 \mathrm{t} \mathrm{ha}^{-1}\right)$ is much lower than the world average (24 tha $\left.\mathrm{t}^{-1}\right)$ (Hurelbrink et al., 1993; Ikeda, 1996). Among biotic and abiotic constraints of tomato cultivation, insect-transmitted virus diseases are economically important in terms of prevalence, severity and damage caused to the crop.

\footnotetext{
1 Department of Agricultural Biology, Faculty of Agriculture, University of Peradeniya, Sri Lanka * Corresponding author: kprasannath@gmail.com
} 
Tomato yellow leaf curl virus (TYLCV), tomato spotted wilt virus (TSWV) and tomato curly top virus (TCTV) are some of the common viruses affecting the quality and quantity of tomato yield in many tropical and subtropical countries of the world including Sri Lanka. Tomato yellow leaf curl disease, caused by several viruses belonging to the genus Begomovirus of family Geminiviridae (Czosnek, 2008), has been reported at higher incidences in tomato cultivations of Sri Lanka during April to September period (Ariyarathna et al., 2004). It is transmitted by whitefly, Bemisia tabaci (Cohen \& Lapidot, 2007). TSWV and TCTV are transmitted by thrips and leafhoppers respectively (Hogenhout et al., 2008; Bennett, 1971).

Control of plant virus infections is a challenge due to lack of therapeutic measures. Therefore, disease management has to focus on indirect measures such as reduction of insect vector populations through chemical or cultural methods, through natural enemies and induction of systemic resistance in host plants by exogenous application of biotic/abiotic inducers. Control measures in infected regions have traditionally emphasized vector control mainly by pesticides or physical barriers (Lapidot \& Friedmann, 2002). Chemical control has only been partially effective since insect vector populations could reach very high numbers with intensive pesticide use in attempts to eliminate the vector before it transmits the virus. Furthermore, there are concerns that the vector may develop resistance and intense application of pesticides may have deleterious effects on the environment (Palumbo et al., 2001).

Epidemics of existing plant virus diseases and emergence of novel virus diseases have become a serious threat to subsistence and commercial agriculture. Rapidly-expanding global climatic change creates favourable conditions for development and increased spread of plant virus diseases due to direct or indirect impacts on population dynamics of virus-transmitting insect vectors (Pautasso et al., 2012).

As tomato is grown in a wide range of agroecological regions in Sri Lanka, virus disease incidences and population dynamics of virus vectors could be affected by variation of environmental factors (e.g. temperature, rainfall) experienced at different locations. Moreover, pesticide-based systems applied for virus disease management would have impacts on populations of beneficial insects acting as biological control agents of the virus vectors. Therefore, reduction of insect vectors through natural enemies as a non-pesticidal approach would be effective in the management of viral infections. In addition, exogenous application of biotic and abiotic substances leads to synthesis of the defense enzyme peroxidase in tomato tissue. This is an indicator of induced systemic resistance. Therefore, this study was aimed at determining the variation of disease incidence, populations of insect vectors and peroxidase activity of tomato tissues under field conditions, at different locations in two crop management systems. Moreover, possible relationships among virus disease incidence, insect populations, beneficial insects and environmental factors were determined.

\section{METHODOLOGY}

\section{Experimental sites}

A multi-locational experiment was carried out at five locations (Kilinochchi, Mahailluppallama, Kundasale, Peradeniya and Rahangala) across five different agroecological regions, which represented gradations of two key environmental factors that have a direct relation to climate change (Table 1). 
Table 1. Selected experimental sites and their environmental characteristics

\begin{tabular}{lcccc}
\hline Location & $\begin{array}{c}\text { Agro- } \\
\text { ecological } \\
\text { region }\end{array}$ & $\begin{array}{c}\text { Elevation from } \\
\text { mean sea level } \\
(\mathbf{m})\end{array}$ & $\begin{array}{c}\text { Annual } \\
\text { average } \\
\text { rainfall }(\mathbf{m m})\end{array}$ & $\begin{array}{c}\text { Diurnal annual } \\
\text { mean temperature } \\
\left({ }^{\circ} \mathbf{C}\right)\end{array}$ \\
\hline Kilinochchi & $\mathrm{DL}_{3}$ & 15 & 950 & 27.71 \\
Mahailluppallama & $\mathrm{DL}_{1}$ & 117 & 1000 & 27.61 \\
Kundasale & $\mathrm{IM}_{3}$ & 367 & 1500 & 25.20 \\
Peradeniya & $\mathrm{WM}_{2 \mathrm{~b}}$ & 496 & 2100 & 25.43 \\
Rahangala & $\mathrm{IU}_{3 \mathrm{~d}}$ & 1558 & 1450 & 19.61 \\
\hline
\end{tabular}

Source: Mapa et al. (2010); Punyawardana (2008)

\section{Crop establishment and management}

Tomato cv. Thilina was selected for cultivation as it is a popular variety among farmers, highly affected by insect-transmitted virus diseases and can be grown in all the identified experimental locations. Field experiments were conducted in Maha 2012/2013. Four weeks old seedlings of tomato were transplanted at a spacing of $80 \mathrm{~cm} \times 50 \mathrm{~cm}$. The field was irrigated depending on the water requirement. Manual weeding was done at 3 and 6 weeks after transplanting. Fertilizers were applied according to recommendations of Department of Agriculture, Sri Lanka.

\section{Treatment structure}

A factorial design with two factors was conducted using six replicates. Two factors, namely the types of crop management system (2 methods; existing management system recommended by the Department of Agriculture, Sri Lanka and a management system with less reliance on pesticides proposed in the present study) and locations (5 levels) were tested. Five locations (e.g. Kilinochchi, Mahailluppallama, Kundasale, Peradeniya and Rahangala) having temperature and rainfall gradients were selected (Table 1). An integrated management package (IMP) using less amount and frequency of insecticides and fungicides was developed for the present study, based on findings of several preliminary experiments conducted at the laboratory and planthouse of the Department of Agricultural Biology, Faculty of Agriculture, University of Peradeniya. The IMP system was combined with the use of cultural practices, generally regarded as safe (GRAS) compounds, application of a talc-based biopesticide, application of a chemical compound to induce host plant resistance and spot application (instead of blanket applications) of insecticides at most needed situations (Table 2).

In comparison to IMP, the following management practices were introduced to the plants treated with the existing system using pesticides recommended by the Department of Agriculture as needed, during the cropping season. Briefly, in the existing management system, seeds were treated with a fungicide (thiram) before sowing in the nursery. Mancozeb was sprayed thrice per cropping season at the rate of $1 \mathrm{~kg} / \mathrm{ha}$ to control early and late blight. Abamectin, a miticide was applied twice at the rate of $350 \mathrm{~mL} / \mathrm{ha}$ to control mites. Imidacloprid, an insecticide was sprayed to foliage twice at the rate of $400 \mathrm{~mL} / \mathrm{ha}$ to control whiteflies, thrips and hoppers. Chlorfluazuron foliage application was done twice at the rate of $600 \mathrm{~mL} / \mathrm{ha}$ to control tomato pod borers. 
Table 2. Components of the integrated management package (IMP) evaluated in the present study

\begin{tabular}{|c|c|}
\hline Activity & Details of the activity \\
\hline $\begin{array}{l}\text { Establishment of border and barrier crop } \\
\text { by growing maize }\end{array}$ & $\begin{array}{l}\text { Two border rows of maize around each plot and a } \\
\text { thicker barrier ( } 5 \text { rows) of maize plants in between } \\
\text { the crops maintained under two crop management } \\
\text { systems were established } 3 \text { weeks prior to the } \\
\text { establishment of tomato crop }\end{array}$ \\
\hline Seed treatments & $\begin{array}{l}\text { Tomato seeds were soaked in } 1 \% \text { Clorox solution (a } \\
\text { commercial bleach solution) for } 30 \mathrm{~min} \text { before } \\
\text { nursery establishment }\end{array}$ \\
\hline Soil drenching & $\begin{array}{l}50 \mathrm{~mL} \text { of } 2 \%(\mathrm{w} / \mathrm{v}) \text { bleach solution (prepared from } \\
\text { commercial bleaching powder) was applied per } \\
\text { planting hole, prior to transplanting of tomato }\end{array}$ \\
\hline Mulching the land & $\begin{array}{l}\text { Mulches were applied around the plants to suppress } \\
\text { the growth of weeds; to promote ground dwelling } \\
\text { predatory fauna (according to availability at each } \\
\text { location, rice straw was used at Mahailluppallama } \\
\text { and Kilinochchi, guinea grass was used at Kundasale } \\
\text { and Peradeniya and signal grass was used at } \\
\text { Rahangala at a rate of } 10 \mathrm{~kg} / 25 \mathrm{~m}^{2} \text { ) }\end{array}$ \\
\hline Hanging of sticky traps & $\begin{array}{l}\text { Made out of yellow coloured Perspex sheets } \\
\text { (approximately } 15 \mathrm{~cm} \times 15 \mathrm{~cm} \text { ) and covered with } \\
\text { Vaseline. Those were placed above the canopy level } \\
\text { (i.e. about } 15 \mathrm{~cm} \text { ) at a density of } 4 \text { sheets per plot } \\
\text { having the area of } 25 \mathrm{~m}^{2}\end{array}$ \\
\hline $\begin{array}{l}\text { Application of sodium bicarbonate } \\
\text { solution }\end{array}$ & $\begin{array}{l}0.1 \% \mathrm{NaHCO}_{3} \text { was sprayed as a foliar spray at three- } \\
\text { week intervals }\end{array}$ \\
\hline $\begin{array}{l}\text { Application of talc-based biopesticide } \\
\text { (Bacillus megaterium) }\end{array}$ & $\begin{array}{l}\text { Biopesticide having a bacterial cell concentration of } \\
10^{6} \mathrm{cfu} / \mathrm{mL} \text { was applied as a foliar spray once per } \\
\text { cropping season }\end{array}$ \\
\hline $\begin{array}{l}\text { Maintaining naturally growing } \\
\text { flowering plants in order to promote } \\
\text { natural enemies }\end{array}$ & $\begin{array}{l}\text { Weeds only around the crops were removed; } \\
\text { any over growing weeds that disturbed the crop were } \\
\text { removed }\end{array}$ \\
\hline $\begin{array}{l}\text { Application of neem seed kernel extract } \\
\text { (NSKE) }\end{array}$ & $\begin{array}{l}5 \%(\mathrm{w} / \mathrm{v}) \mathrm{NSKE} \text { was sprayed as a foliar spray once } \\
\text { per cropping season (during the crop development } \\
\text { stage) }\end{array}$ \\
\hline Application of salicylic acid & $\begin{array}{l}400 \mu \mathrm{M} \text { salicylic acid was sprayed as a foliar spray at } \\
\text { an interval of one month (a total of three applications } \\
\text { each at initial, crop development and mid season } \\
\text { stages) }\end{array}$ \\
\hline $\begin{array}{l}\text { Use of insecticides } \\
\text { (imidacloprid and abamectin) }\end{array}$ & Applied as a spot treatment once per cropping season \\
\hline
\end{tabular}

\section{Sample collection for peroxidase assay}

Leaf samples were collected from apparently-healthy tomato plants of all locations subjected to the two types of crop management systems, at the first harvesting (i.e. latter stage of the midseason of the crop). Leaf samples were snap frozen in liquid nitrogen immediately after detachment from the plants and stored at $-80{ }^{\circ} \mathrm{C}$ until peroxidase assay. 


\section{Assay of peroxidase}

Leaf samples $(1 \mathrm{~g})$ were homogenized in $2 \mathrm{~mL}$ of $0.1 \mathrm{M}$ phosphate buffer (extraction buffer), $\mathrm{pH}$ 7.0 at $4{ }^{\circ} \mathrm{C}$. The homogenate was centrifuged at $16,000 \mathrm{~g}$ at $4{ }^{\circ} \mathrm{C}$ for $20 \mathrm{~min}$ and the supernatant was used as the enzyme source. One $\mathrm{mL}$ of enzyme supernatant was diluted using extraction buffer (1:10). The reaction mixture consisted of $1.5 \mathrm{~mL}$ of $0.05 \mathrm{M}$ pyrogallol, $0.5 \mathrm{~mL}$ of enzyme dilute and $0.5 \mathrm{~mL}$ of $1 \% \mathrm{H}_{2} \mathrm{O}_{2}$. The changes in absorbance at $420 \mathrm{~nm}$ were recorded at $30 \mathrm{~s}$ intervals for $3 \mathrm{~min}$. The enzyme activity is expressed as changes in the absorbance $\min ^{-1} \mathrm{~g}^{-1}$ leaf tissue (Hammerschmidt et al., 1982).

\section{Data collection}

Incidence of different types of virus diseases of tomato was recorded over four crop growth stages, namely initial, crop development, midseason and late season (Anon., 1986). The four different crop growth stages were used for data collection instead of days after transplanting, due to variations of the environmental factors of the five locations, hence variations of time taken to reach different crop growth stages. Seedlings, transplanted in field, were monitored biweekly and the number of plants showing typical virus disease symptoms was recorded as percentage disease incidence of different types of virus diseases for plants treated with the IMP and the existing management methods. Types of virus diseases and disease incidence were identified based on the typical symptoms shown by respective virus diseases according to disease diagnosis manuals and descriptions of previous studies (Whitfield et al., 2005; Chen et al., 2010; Samarakoon et al., 2012). The tomato plants remained as asymptomatic at the time of observation were designated as healthy plants.

Abundance of different types of insect virus vectors and beneficial insects were quantified using counting techniques, namely visual observations ( 6 plants per plot) and sweep netting over the four different crop growth stages under two crop management systems. Insects, already identified as possible plant virus vectors of tomato (e.g. whiteflies, thrips and planthoppers/leafhoppers), were quantified in the present study. Generalist predators (e.g. spiders, ladybird beetles) and hymenopteran parasitoids were counted. Identification of beneficial insects was based on morphological characters. Weather data (e.g. ambient temperature and rainfall) during the cultivation period were collected from each experimental site.

\section{Detection of Begomovirus in TYLCVD plant samples}

Leaf samples of tomato plants showing typical characteristic of TYLCVD symptoms and healthylooking were collected. The genomic DNA was extracted from apparently infected and healthy samples using CTAB method described by Lodhi et al. (1994) with slight modifications.

PCR amplification was carried out in a $25 \mu \mathrm{L}$ reaction volume containing $1 \mu \mathrm{L}$ of template genomic DNA, $12.5 \mu \mathrm{L}$ of master mix (promega Corporation, USA), $7.5 \mu \mathrm{L}$ of nuclease free water (Promega Corporation, USA), $2 \mu \mathrm{L}$ each of forward and reverse primers. Begomovirus specific primer pair AV 494 (GCC (C/T)AT (G/A)TA (T/C)AG (A/G)AA GCC (A/C)AG) and AC 1048 (GG(A/G) TT(A/G/T) GA(G/A) GCA TG(T/A/C) GTA CAT G) was used to prime the amplification of $550 \mathrm{bp}$ products (Brown and Simone, 1994). DNA extracted from asymptomatic plants was used as the negative control. The PCR programme consisted of an initial denaturation at $94{ }^{\circ} \mathrm{C}$ for $5 \mathrm{~min}$ followed by 30 cycles of denaturation at $94{ }^{\circ} \mathrm{C}$ for $30 \mathrm{~s}$, annealing at $50{ }^{\circ} \mathrm{C}$ for 30 $\mathrm{s}$ and extension at $72{ }^{\circ} \mathrm{C}$ for $45 \mathrm{~s}$ followed by a final extension at $72{ }^{\circ} \mathrm{C}$ for $10 \mathrm{~min}$ (Samarakoon et al., 2012). PCR products (5 $\mu \mathrm{L}$ of each) were subjected to $1 \%(\mathrm{w} / \mathrm{v})$ agarose gel electrophoresis with 100 bp ladder and UV illumination was done after staining with ethidium bromide. 


\section{Data analysis}

Proc. PROBIT was done for the data analysis of virus disease incidence. CATMOD procedure was used for the analysis of insect count data subjected to the SAS 9.1 package. Above data were analyzed according to nested design. Analysis of variance (ANOVA) was done to determine location effect, crop management effect and their interaction effects on peroxidase activity of leaf tissues and means were separated using Duncan's Multiple Range Test (DMRT). Statistical significance was tested at $\alpha=0.05$.

Relationships between several parameters, namely incidence of virus diseases vs. vector population, incidence of virus diseases vs. climatic parameters, vector population vs. climatic parameters, beneficial insect population vs. incidence of virus diseases and climatic parameters vs. beneficial insects were analyzed by regression analysis. Only TYLCVD, TCTVD and TSWVD were considered as the amount of virus diseases during the analysis. Whiteflies, thrips and hoppers were included in the insect vector population.

\section{RESULTS AND DISCUSSION}

Fig.s 1 and 2 show the variation of daily temperature and daily rainfall respectively, across the locations and throughout the cropping season. Throughout the experimental period, Rahangala reported the lowest avearge daily temperature having a mean day temperature of $20.7^{\circ} \mathrm{C}$. The highest mean day temperature of $26.7{ }^{\circ} \mathrm{C}$ throughout the experimental period was recorded at Kilinochchi.

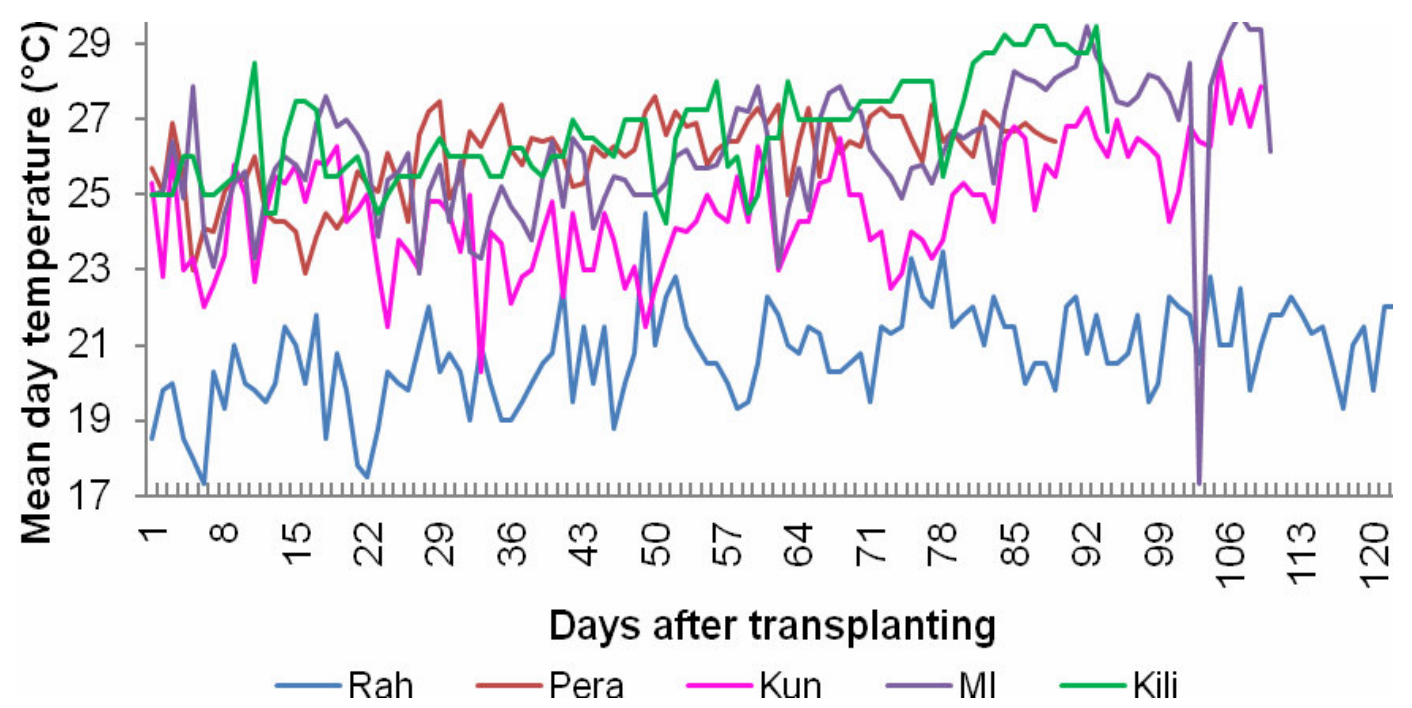

Fig. 1. Mean day temperature during the cropping season at the five selected sites 
Prasannath et al.
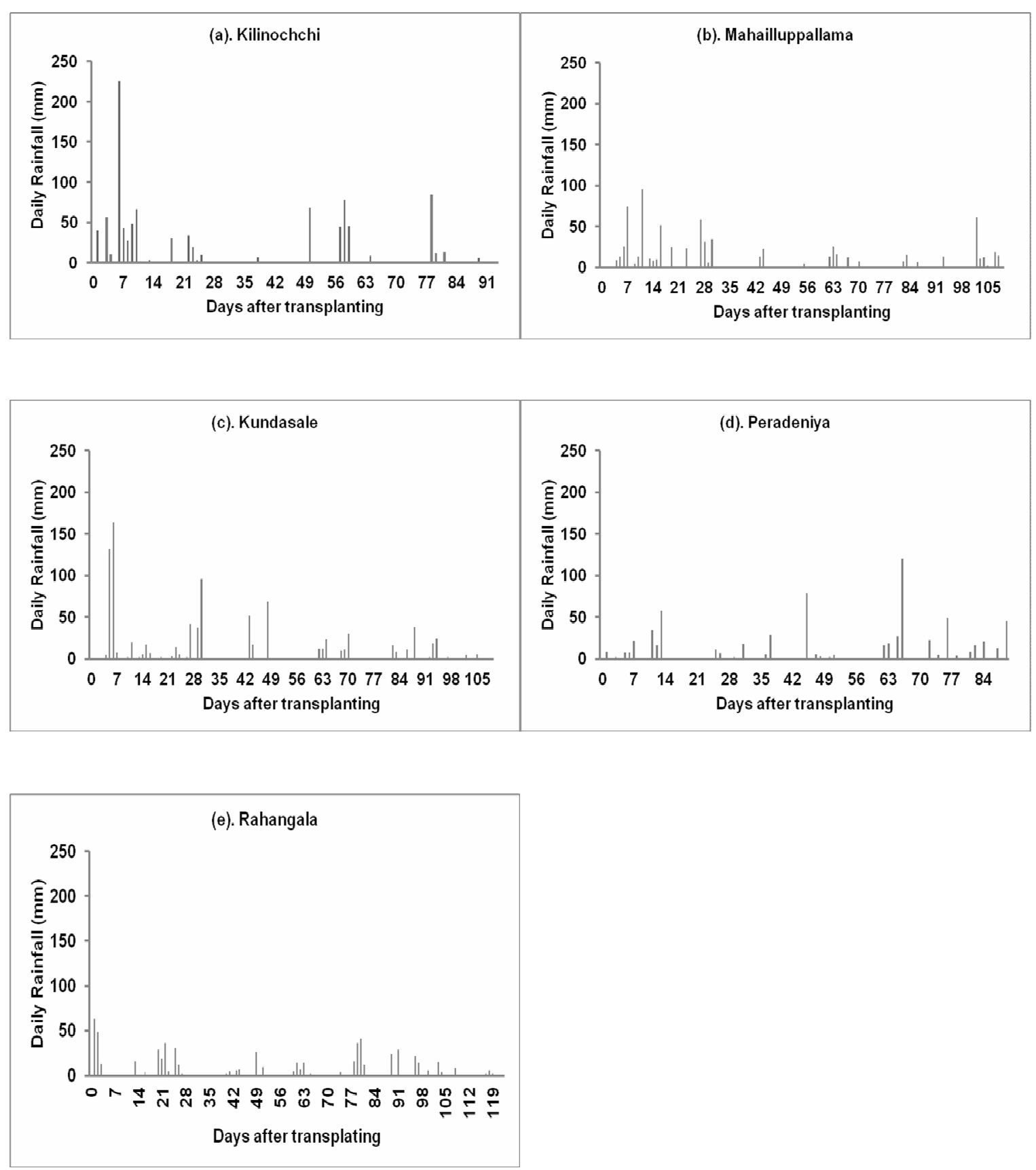

Fig. 2. Daily rainfall during the cropping season at the five experimental sites

\section{Incidence of virus diseases}

Figure 3 shows the total virus disease incidence of tomato grown under two management systems at five locations. This is the summation of separately identified virus diseases (e.g. TYLCVD, TSWVD and TCTVD). 
(a). Kilinochchi

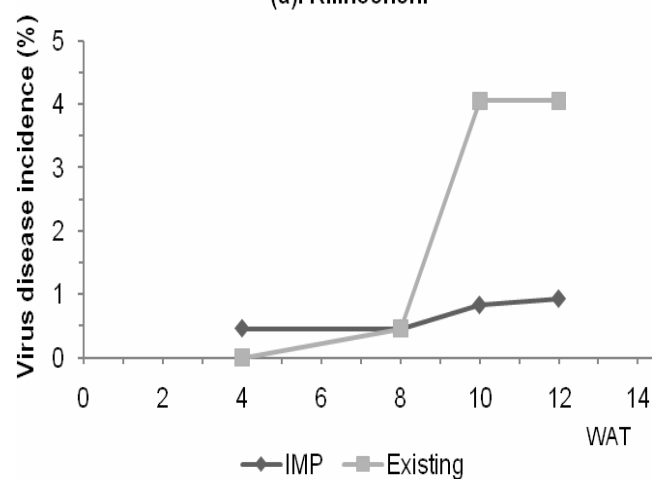

(c). Kundasale

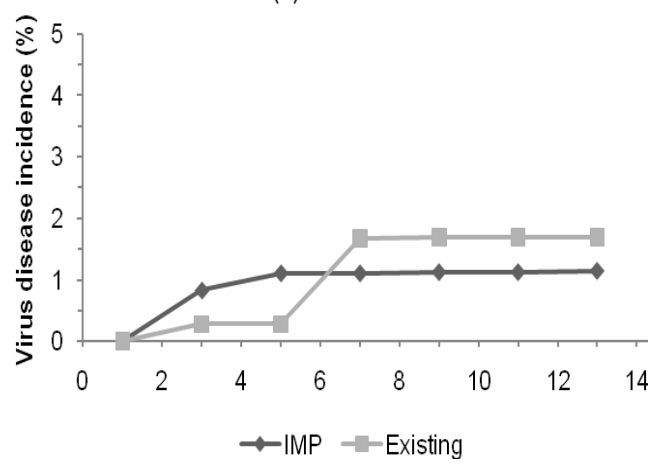

(e). Rahangala

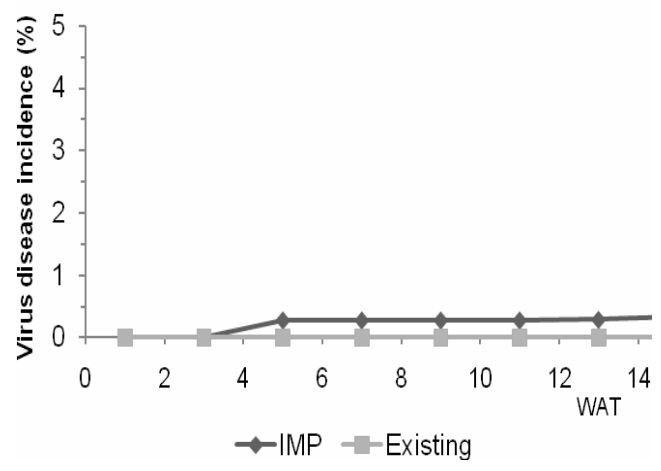

(b). Mahailluppallama

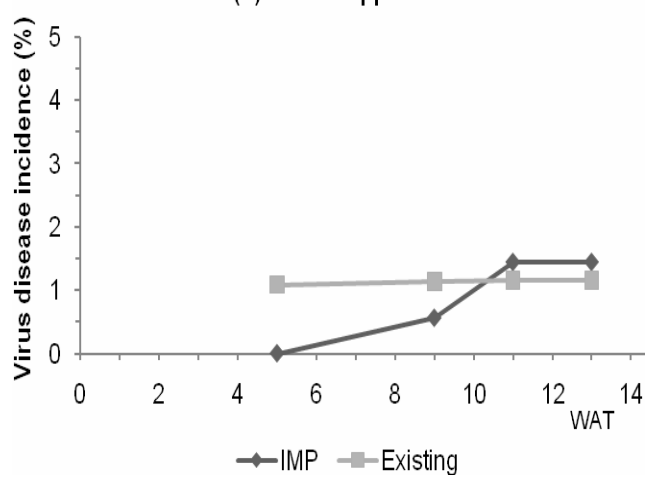

(d). Peradeniya

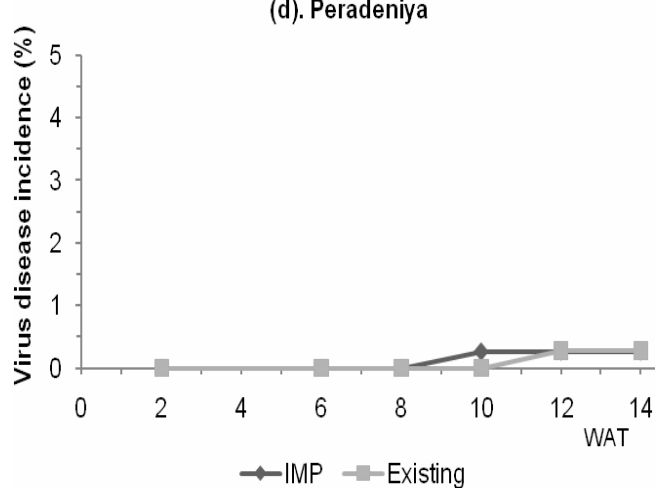

Fig. 3. Percentage virus disease incidence of tomato grown at five locations under two management systems

In the plants treated with the existing management practices, incidence of total virus diseases varied significantly $(\mathrm{p}<0.05)$ among locations. However, a significant difference in virus disease incidence was not observed in plants treated with IMP among the different locations. Moreover, there was no significant difference $(\mathrm{p}=0.05)$ in virus disease incidence between the plants treated 
with the two types of crop management practices at each location, except at Kilinochchi where virus disease incidence was significantly lower in the IMP treatment compared to the existing crop management. At all locations, in plants treated with both management systems, disease incidence followed a typical virus disease progression curve, with an initial gradual increase of cumulative disease incidence and a subsequent slowing down.

Findings of the present study revealed that there was no significant difference between the two types of management systems, indicating the equal efficiency of IMP treatments as the existing system of virus disease management. This could be due to similar effects caused by the application of insecticides and the components present in the IMP system towards increasing vector death rate, decreasing vector immigration rate and increasing vector departure rate (Holt et al., 1999). This possibility agrees with the potential for reducing disease incidence of TYLCVD and TSWVD significantly by integrating multiple management practices as highlighted by Hilje et al. (2001) and Culbreath et al. (2003), respectively. Or else it could be due to the ineffectiveness of insecticides for controlling thrips as experienced with tomato spotted wilt virus in peanut (Chamberlin et al., 1993). This was because the insecticide applications were ineffective in preventing plant feeding and inoculation by viruliferous adult thrips that migrate from areas outside the field.

\section{Types of virus diseases}

TYLCVD, TSWVD and TCTVD were identified at the experimental sites based on visual observations. Yellow (chlorotic) leaf edges, upward leaf cupping, leaf mottling, reduced leaf size and stunted plants were considered as the typical TYLCVD symptoms (Fig. 4).

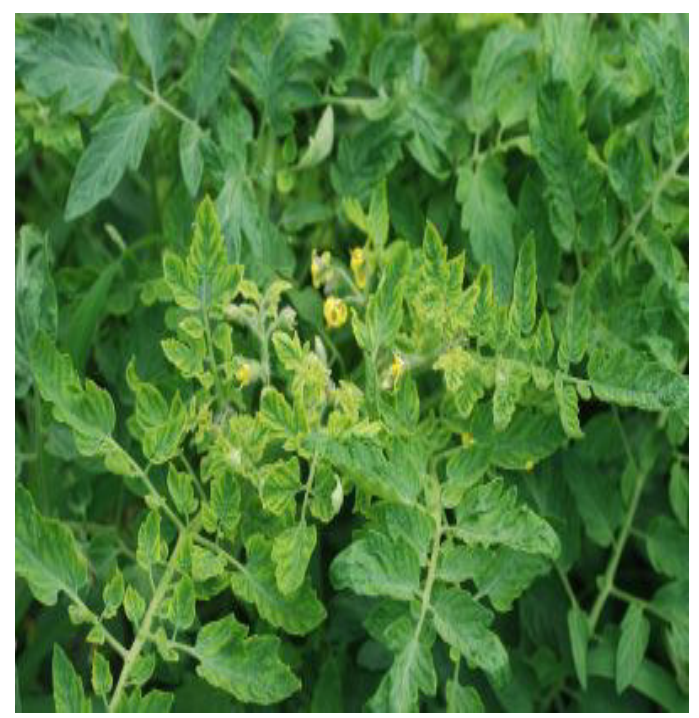

Tomato leaves showing typical TYLCVD symptoms (Czosnek, 2007)

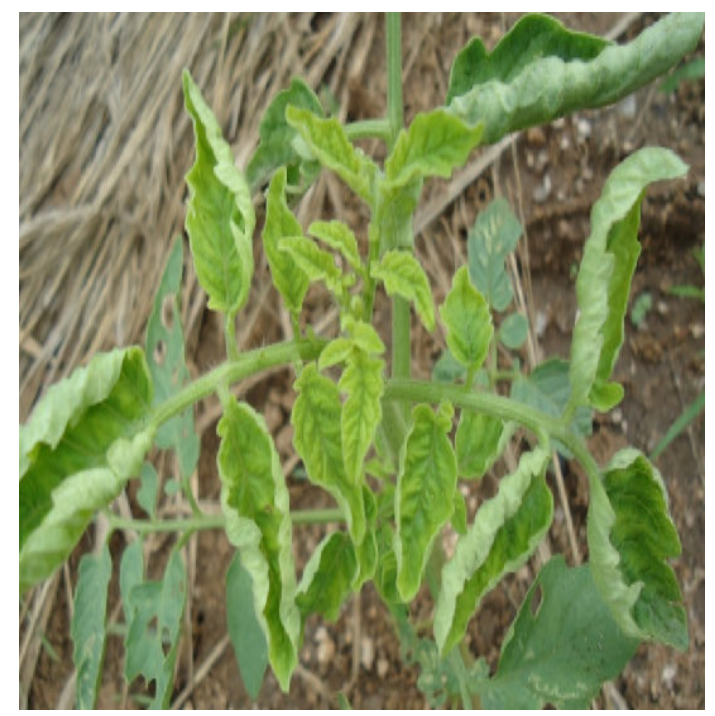

Tomato leaves showing TYLCVD symptoms in the present study

\section{Fig. 4. Comparison of TYLCVD symptoms using a reference pictorial guide}

Leaflets rolled up and twisted sharply, exposing their undersurface clearly, foliage with stiff and leathery nature, the entire plant was having a peculiar dull yellow colour with leaflets having 
prominent purple coloured veins and stunted plants were identified as TCTV-infected plants (Fig. $5)$.

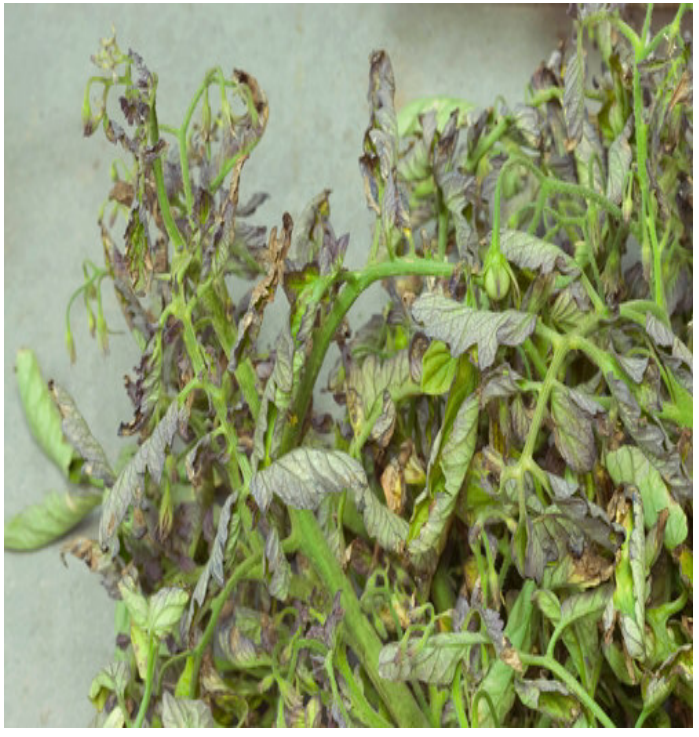

Tomato leaves showing typical TCTVD symptoms (Jones et al., 2008)

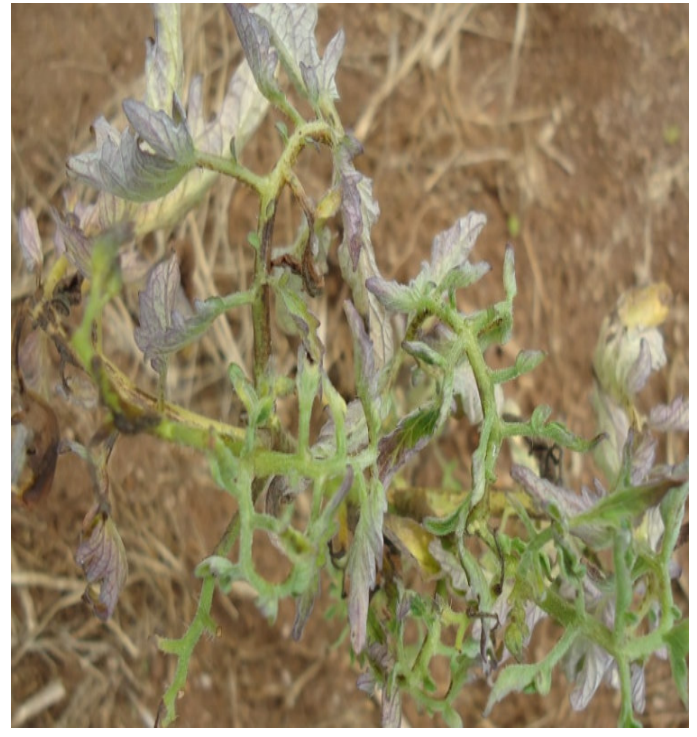

Tomato leaves showing TCTVD symptoms in the present study

Fig. 5. Comparison of TCTVD symptoms using a reference pictorial guide

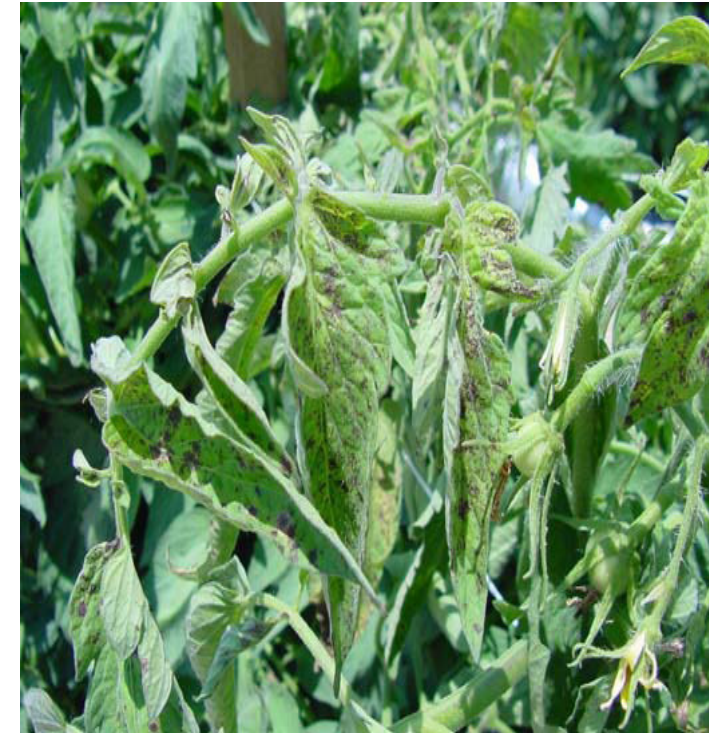

Tomato leaves showing typical TSWVD symptoms (Ullman et al., 2002)

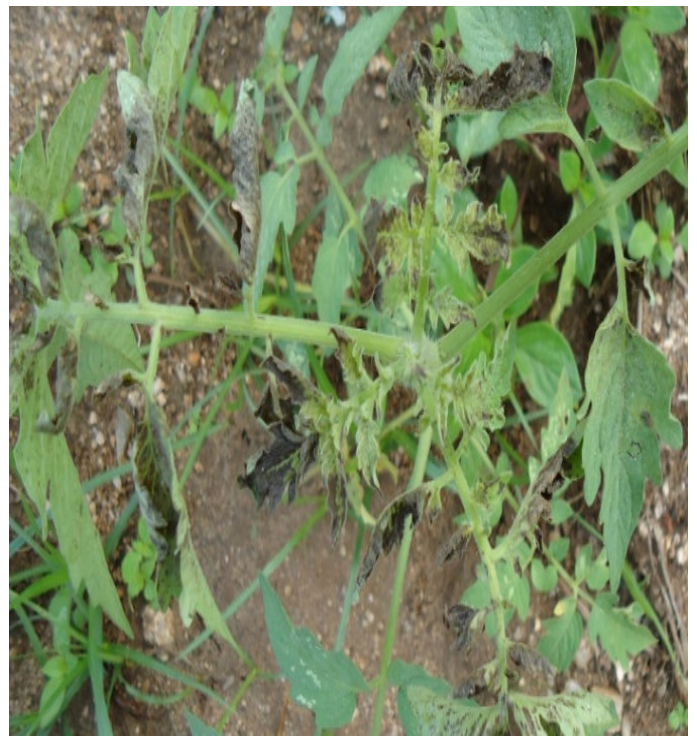

Tomato leaves showing TSWVD symptoms in the present study

Fig. 6. Comparison of TSWVD symptoms using a reference pictorial guide 
TSWV-infected plants were differentiated based on the small, light brown flecks that first appeared on leaves and turned brown later with a general browning of leaves at the end (Fig. 6).

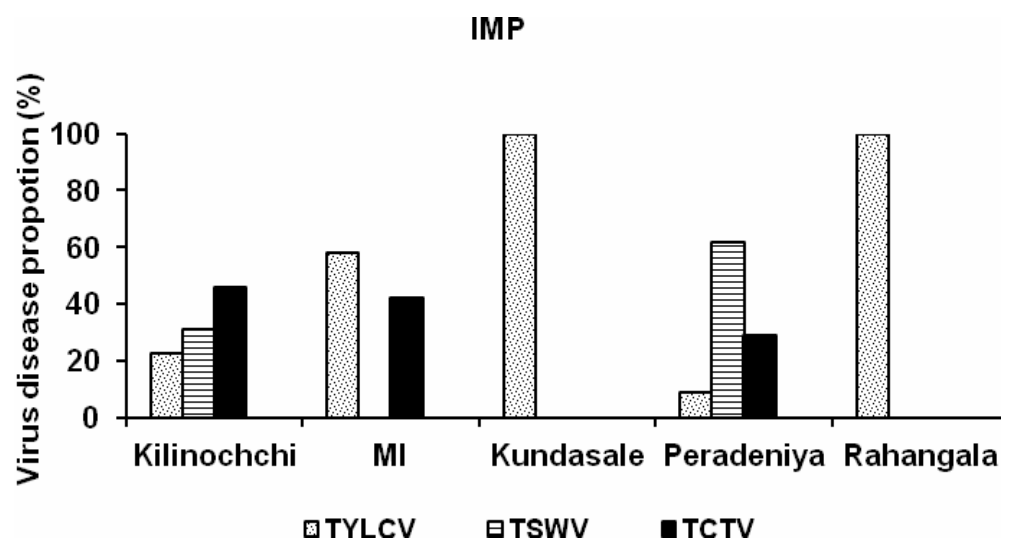

\section{Existing}

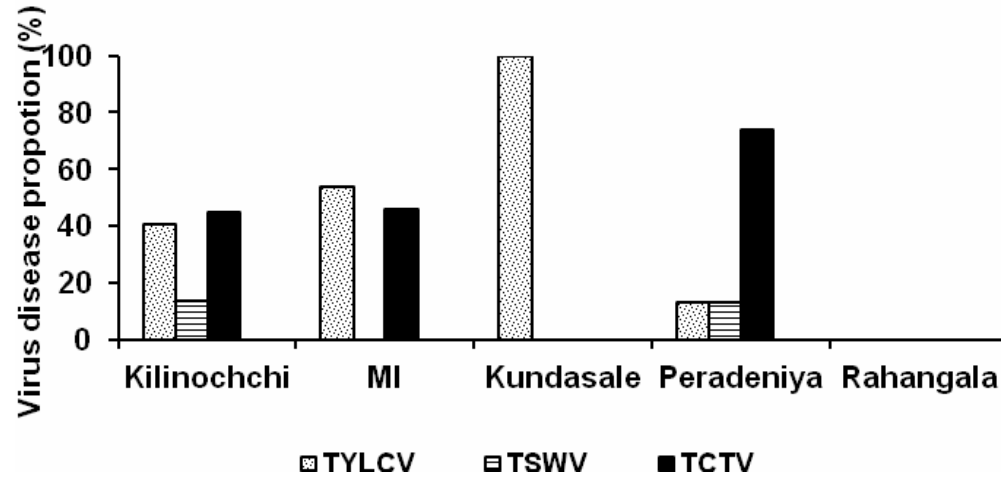

Fig. 7. Proportion of different virus diseases out of the total incidence of virus diseases in tomato at different locations grown under two management systems

The incidence of the types of virus diseases of tomato varied among locations and between the two types of management systems. Plants grown at Kundasale reported only TYLCVD under both management systems. Rahangala reported symptoms of TYLCVD only under IMP system but no any type of virus diseases under the existing management system. A clear relationship between the types of virus diseases and locations or types of management systems could not be identified. Field symptoms have been used to identify TYLCV-infested plants and healthy plants in a study done by Rahman et al. (2006) when determining relationship of whitefly population buildup and TYLCVD development. Moreover, TCTVD shows typical purple colouration on foliage. Hence, the method used in this study to determine the types of diseases is an acceptable measure. 


\section{Confirmation of the presence of Begomovirus in plants showing symptoms of TYLCVD}

PCR amplification using AV 494 and AC 1048 primers confirmed the presence of Begomoviruses in TYLCVD samples selected based on field symptoms. It also confirmed the absence of this virus in asymptomatic plants selected based on visual observations. TYLCVD samples produced the PCR product having the expected size of $550 \mathrm{bp}$ and no such amplicon was observed in asymptomatic plant samples or in control sample containing water (Fig. 8).

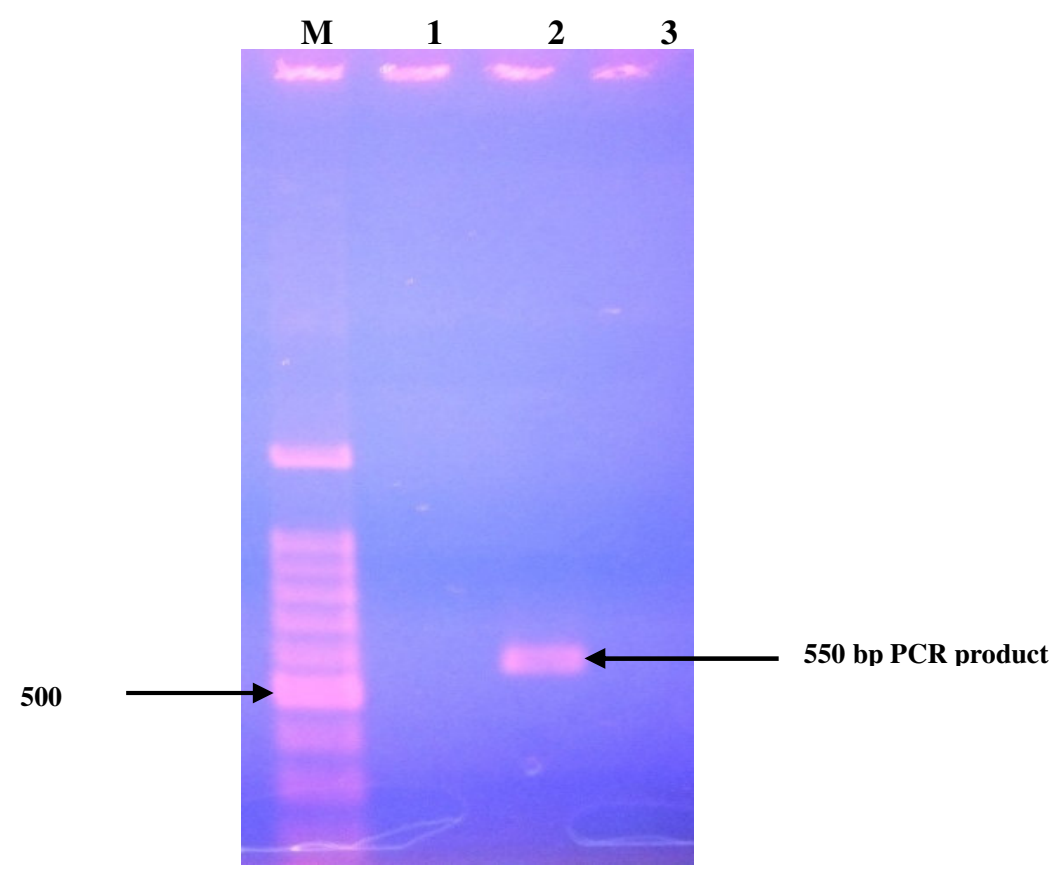

Fig. 8. PCR performed for apparently healthy plants and plants showing typical TYLCVD symptoms, Lanes M: 100 bp ladder, 1: asymptomatic plant sample, 2: TYLCV infected sample, 3: Water control 


\section{Abundance of insect vectors and beneficial insects}

(a). Kilinochchi

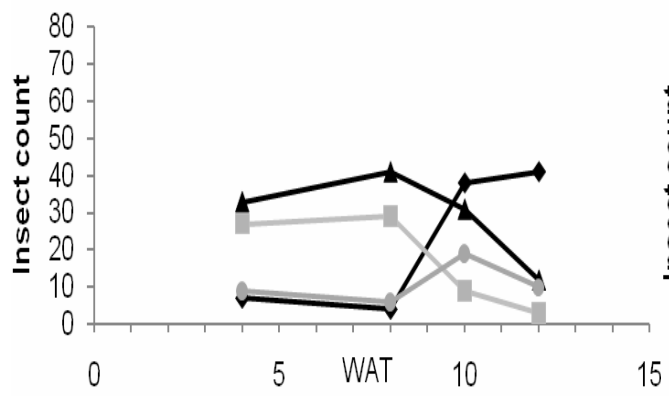

$\leftarrow$ Vectors-IMP $\quad-$-Beneficial-Existing

\pm Beneficial-IMP $\quad-$-Vectors-Existing

(c). Kundasale

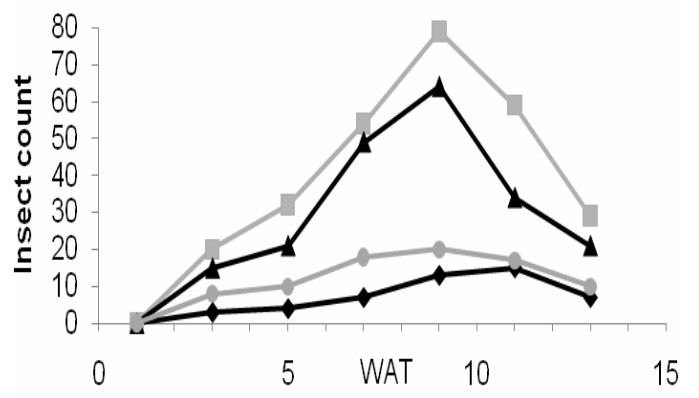

$\bullet$ Vectors-IMP $\quad-$-Beneficial-Existing

$\rightarrow$ Beneficial-IMP $\Rightarrow$-Vectors-Existing

(e). Rahangala

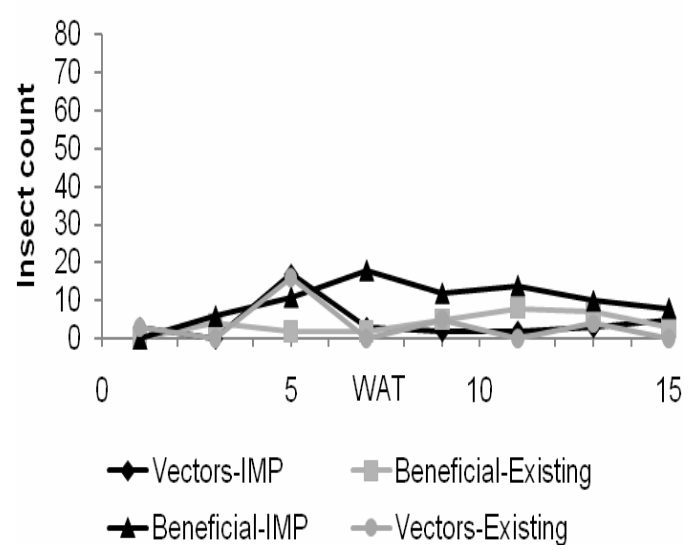

(b). Mahailluppllama

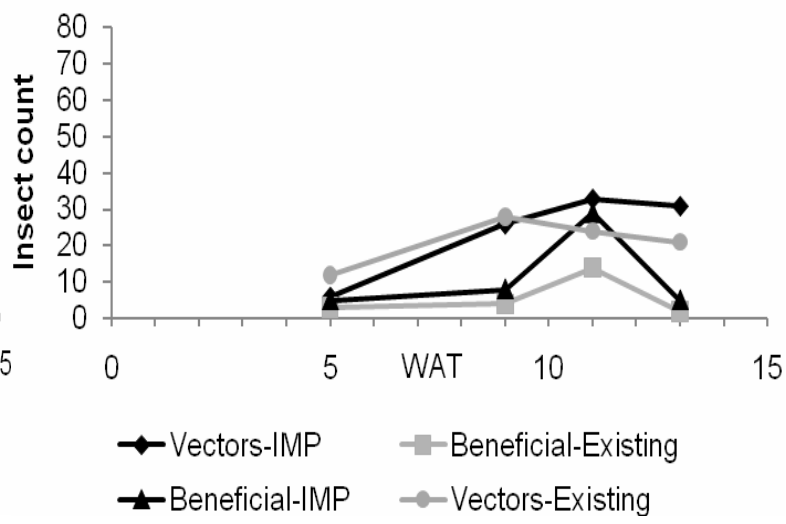

(d). Peradeniya

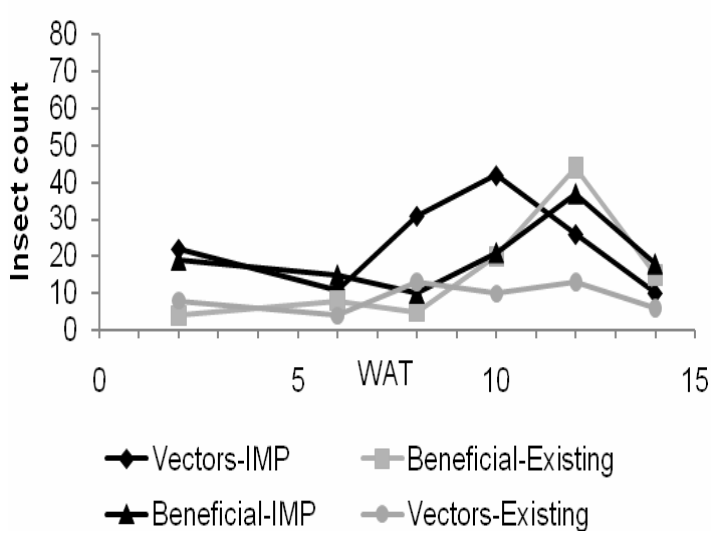

Fig. 9. Abundance of insect vectors and beneficial insects in tomato fields grown under two management systems at five different locations 
Vector populations between IMP and existing management systems did not differ significantly $(\mathrm{p}=0.05)$. However, vector populations differed significantly among locations. Moreover, the effect of management system on vector population was significantly influenced by the location effect, thus indicating a significant location $\mathrm{x}$ management system interaction. In general, the beneficial insect population was significantly higher under the IMP system than under the existing management system. Moreover, the beneficial insect populations varied significantly $(\mathrm{p}<0.05)$ among locations. The effect of management system on beneficial insect population was significantly influenced by the location effect. High abundance of total natural enemies, predatory insects and natural enemies of nymphal stages of virus vectors in organically maintained and IPM treated cotton fields in comparison to chemical treated fields of a six-year comparative study (Swezey et al., 2006) agrees with our findings on higher beneficial insects under IMP treated fields.

Abundance of insect vectors was higher at Kilinochchi and Mahailuppallama under both management systems in comparison to beneficial insect counts of the two locations. In contrast, under both management systems, beneficial insect counts were higher than those of the insect vectors at Kundasale, Peradeniya and Rahangala (Fig. 9).

Despite the presence of higher beneficial insect populations, virus disease development has taken place at varying levels of incidence (except at Rahangala under the existing system) at different locations under the two management systems. A possible reason could be the lack of effective predators, and parasitoids for the control of insect vectors transmitting TYLCVD, TSWVD and TCTVD within the beneficial insects counted in the present study. If not, it could be due to the inefficiency of the available beneficial insects in controlling the insect vectors under field conditions. It is because, we counted the generalist predators (e.g. spiders, ladybird beetles) and hymenopteran parasitoids in the present study, but not specific predators and parasitoids of the vectors of TYLCVD, TSWVD and TCTVD. According to Ramappa et al. (1998), natural enemies have the potential to impose a sustained mortality on $B$. tabaci. However, it does not appear to happen in practice as the $B$. tabaci present in the tomato crop are mostly adults rather nymphs. These adults are widely dispersed and transitory and appear to suffer little mortality from predators and parasites while on tomato.

\section{Composition of insect vector population}

IMP

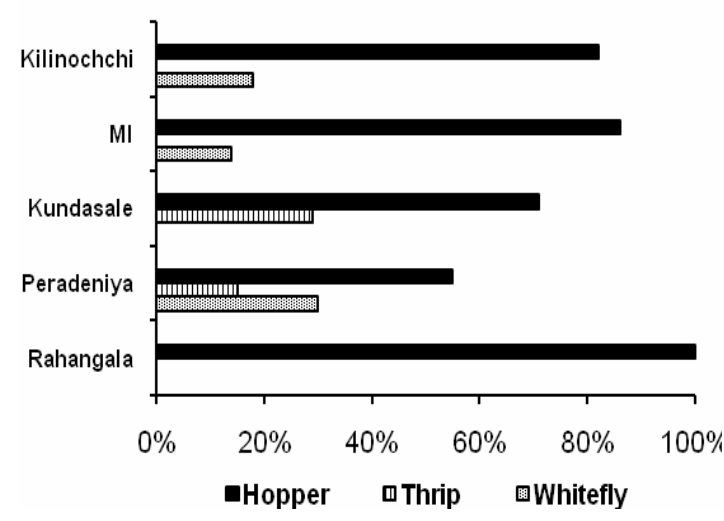

Existing

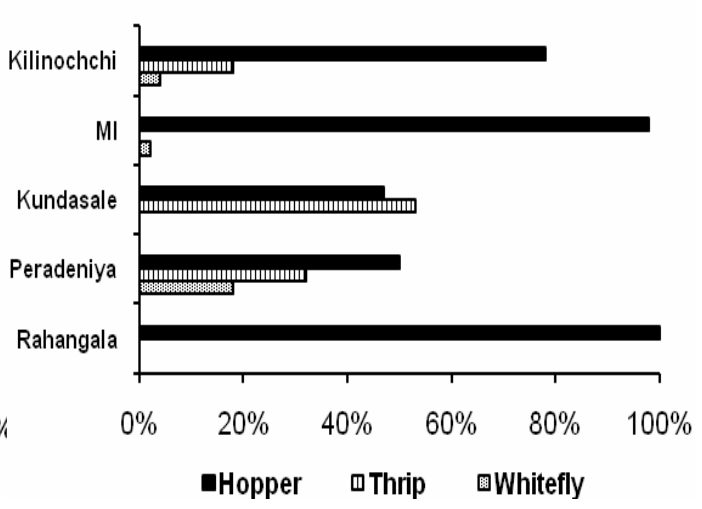

Fig. 10. Percentage proportion of different insect vector populations with respect to the total population of hoppers, thrips and whiteflies in tomato fields at different locations grown under two management systems 
Percentage proportion of insect vectors in terms of hoppers, thrips and whiteflies at five experimental locations under two management systems are given in Fig. 10. Percentage of hoppers was higher under both management systems at all locations. Under both management systems, hoppers were the only type of insect vectors reported at Rahangala. Percentage of thrip population was comparatively higher at all locations, except at Rahangla under the existing management system, despite the higher reliance on insecticides. Inefficiency of insecticides in controlling TSWVD vectored by thrips has been highlighted by Chamberlin et al. (1993) and Culbreath et al. (2003). Moreover, according to Culbreath et al. (2003), use of some insecticides has even resulted in an increased incidence of spotted wilt virus disease in peanut.

Even though TYLCVD was the only recorded disease at Kundasale under both management systems and Rahangala under the IMP system, whiteflies, the vector of the TYLCVD were not reported. Similarly, no thrips were reported though TSWVD was present at Kilinochchi under the IMP system.

Several authors (Mehta et al., 1994; Gupta, 2000; Paul, 2002 and Parvin, 2002) reported that increase of whitefly population is positively correlated with the spread of TYLCV in the field. Accordingly, lower disease incidence observed especially at Rahangala could be related to the lower or no abundance of vectors. As reported by Rahman et al. (2006), the number of whiteflies caught under field conditions could be reduced drastically due to rainfall, maturity of the crop which is not preferred by the vectors as well as availability of preferred weedy plants outside the field. Behaviour of thrips shows similarities to that of whiteflies, thus underestimating their abundance.

\section{Results of regression analysis}

Virus disease incidence showed a significantly positive but weaker linear relationship with mean day temperature in tomato fields $\left(\mathrm{R}^{2}=22.1 \% ; \mathrm{p}=0.01\right)$. This agrees with the positive correlation of whitefly population buildup in tomato fields with temperature that has been reported by Gupta (2000), Sultana (2001), Paul (2002), Haque (2002) and Parvin (2002). Rahman et al. (2006) also reported a weak positive quadratic polynomial relationship between temperature and whitefly population build up in tomato fields. However, in the present study, significant relationship was not observed between virus disease incidence and the rainfall. Similar poor correlation of weekly rainfall and humidity with cotton leaf curl virus disease, a begomovirus disease transmitted by whitefly intensity has been reported (Akhtar et al., 2002; Khan et al., 1998).

In the present study, a significantly positive relationship was found between the incidence of virus diseases and vector population $\left(\mathrm{R}^{2}=33.8 \%\right.$; $\left.\mathrm{p}=0.001\right)$. Rahman et al. (2006), Mehta et al. (1994), Gupta (2000), Paul (2002) and Parvin (2002) have reported an increase of whitefly population and its positive correlation with the spread of TYLCVD under field conditions. However, Ssekyewa $e t$ al. (2007) reported that virus occurrence varied in space and time, and with management practices, crop development stage, and weather conditions based on field experiments conducted on TYLCV and tomato leaf curl virus (ToLCV) using two crop management systems (i.e. chemical pesticide and non-pesticidal application).

A polynomial relationship $\left(\mathrm{R}^{2}=22.2 \%\right)$ was observed between beneficial insect population and average daily temperature, indicating the maximum beneficial insect population at $23.6{ }^{\circ} \mathrm{C}$ and a decline thereafter. However, there was no significant relationship between beneficial insect population and rainfall. No relationship was found between the beneficial insect population and disease incidence though a negative relationship was expected. This could be due to the reason that, though there were possible predators and hymenopteran parasitoids were found, they may not 
be the specific ones to destroy the respective insect vectors of these diseases (highest number represented by spiders and ladybird beetle adults).

\section{Peroxidase assay}

Peroxidase activity of tomato tissues was significantly $(\mathrm{p}<0.05)$ different among locations (Fig. 11). Though there was no significant variation $(\mathrm{p}=0.05)$ between the two management methods on peroxidase activity of tomato tissues, in general, a higher peroxidase activity (1.03 times higher) was quantified in plants treated with IMP under field conditions. Under greenhouse conditions, peroxidase activity has been increased by 4.89 to 6.49 in soybean plants treated with a biotic factor (i.e. formulation of Pseudomonas aeruginosa) and contributed to the reduction of soybean stunt virus infection (Khalimi and Suprapta, 2011). Peroxidase is one of the enzymes contributing to plant resistance to pathogens (Seevers et al., 1971). Peroxidase plays an important role in the process of papilla formation and papilla lignifications through which host plant resist against penetration of pathogens and mechanical damages to cells (Sheng \& Huang, 2001). Also, peroxidase plays a role in resistance through production of hydrogen peroxide, which has a direct effect on microorganisms and has the ability to induce systemic resistance in plants against viral infections (van Loon, 1997). Under heterogeneous field conditions, 1.03 times higher peroxidase activity is appreciable. Yet alternative approaches to increase the peroxidase activity could be investigated.

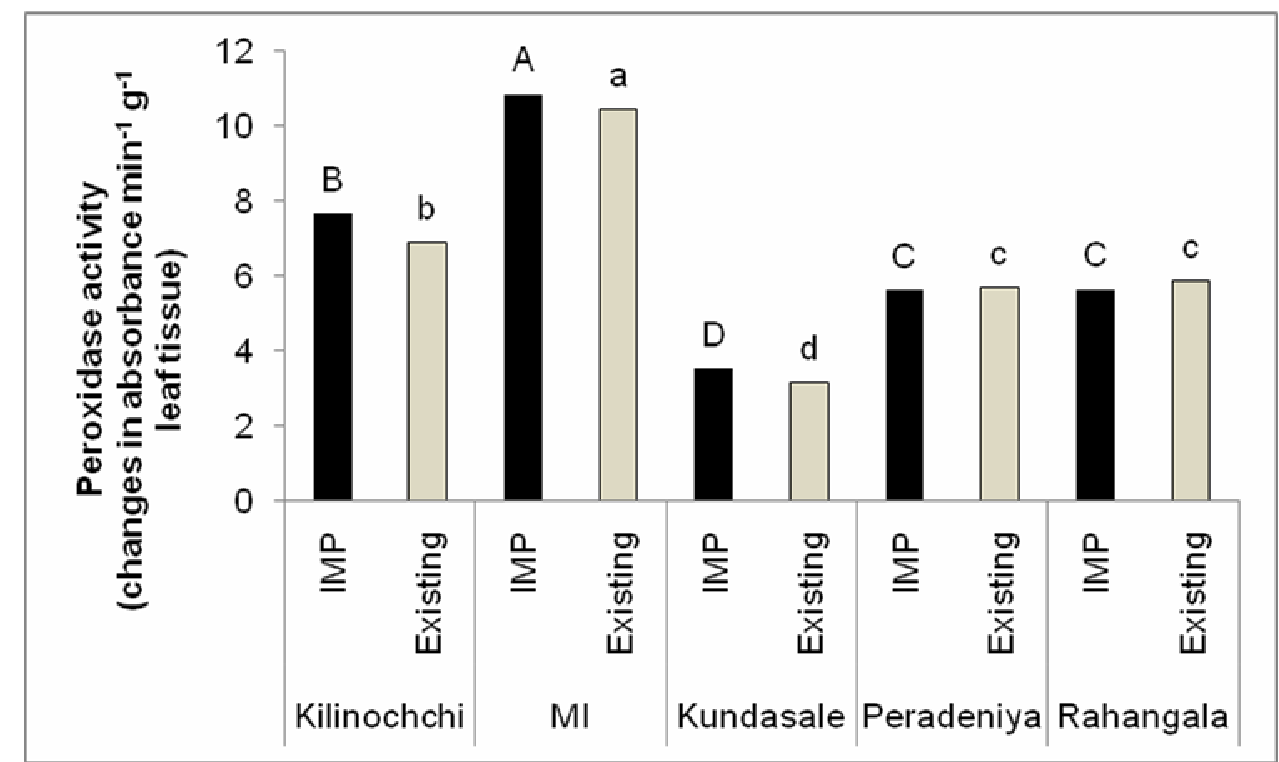

Significance of the variation of peroxidase activity of the IMP treatment between locations is given by upper-case letters. Lower-case letters indicate the significance of the corresponding location-wise variation of peroxidase activity of the existing treatment.

Fig. 11. Peroxidase activity in tomato leaf tissues grown under five different locations under two management systems

\section{CONCLUSIONS}


The IMP system practiced in the present study is as equally-capable as the existing management system which relies on more pesticide usage for controlling virus diseases of tomato, namely TYLCVD, TSWVD and TCTVD. Insect vector and beneficial insect populations were significantly influenced by the interaction effect of management system and location. The mean day temperature was weakly related with the virus disease incidence among the experimental locations. Peroxidase activity of tomato tissues was significantly different among locations but has no significant difference between the plants treated with the two crop management systems.

\section{ACKNOWLEDGEMENT}

Authors gratefully acknowledge the financial assistance given by the HETC-QIG-Windows 3 project awarded by the Ministry of Higher Education, Sri Lanka.

\section{REFERENCES}

Akhtar, K.P., Hussain, M. and Khan, A.I. (2002). Cotton leaf curl virus disease severity in relation to environmental conditions. Pakistan Journal of Phytopathology. 15, 1-4.

Anonymous. (1986). Crop water needs. In: Irrigation Water Management. Natural Resources Management and Environment Department, Food and Agriculture Organization, Rome, Italy.

Ariyarathna, I., Liyanage, T. and Sagarika, M. (2004). Virus disease incidence, alternate hosts of pathogens and disease resistance of Tomato in Sri Lanka. Annals of Sri Lanka Department of Agriculture, 6, 13-28.

Bennett, C.W. (1971). The curly top disease of sugarbeet and other plants. Phytopathological Monograph No. 7. American Phytpathological Society, St. Paul, Minnesota, p. 81.

Brown, J.K. and Simone, G.W. (1994). Tomato yellow leaf curl geminivirus. Plant Pathology Circular No. 366. Florida Dept. of Agriculture and Consumer Services, Division of Plant Industry, Gainesville, FL., USA.

Chamberlin, J.R., Todd, J.W., Culbreath, A.K., Johnson, W.C. and Demski, J.W. (1993). Postharvest management of tobacco thrips (Thysanoptera: Thripidae) overwintering in peanut fields. Journal of Entomological Science. 22, 40-45.

Chen, L.F., Brannigan, K., Clark, R. and Gilbertson, R.L. (2010). Characterization of curtoviruses associated with curly top disease of tomato in California and monitoring for these viruses in beet leafhoppers. Plant Disease. 94, 99-108.

Cohen, S. and Lapidot, M. (2007). Appearance and expansion of TYLCV: a historical point of view. In: Czosnek, H. (Ed.) Tomato Yellow Leaf Curl Virus Disease. Springer, The Netherlands. pp. 3-12.

Culbreath, A.K., Todd, J.W. and Brown, S.L. (2003). Epidemiology and management of tomato spotted wilt in peanut. Annual Review of Phytopathology. 41, 53-75.

Czosnek, H. (2007). Tomato yellow leafcurl disease. Springer, Netherlands. 
Czosnek, H. (2008). Tomato Yellow Leaf Curl Virus. pp. 138-145. In: Mahy, B.W.J. and van Regenmortel, M.H.V. (Eds.). Encyclopedia of Virology. Vol. 5. Elsevier, Oxford.

Gupta, N.D. (2000). Occurrence of Tomato yellow leaf curl virus (TYLCV) and Tomato purple vein virus (TPVV) and their effect on growth and yield of tomato. Unpublished MS Thesis. Department of Plant Pathology, BSMRAU, Gazipur. p. 77.

Hammerschmidt, R., Nuckles, E.M. and Kuc, J. (1982). Association of enhanced peroxidase activity with induced systemic resistance of cucumber to Colletotrichum lagenarium. Physiology and Plant Pathology. 20, 73-82.

Haque, M.M. (2002). Effect of conditions of seedling raising and insecticide spray on prevalence of TYLCV and its impact on growth and yield of tomato. Unpublished MS Thesis. Department of Plant Pathology, BSMRAU, Gazipur. p. 91.

Hilje, L., Costa, H.S. and Stansly, P.A. (2001). Cultural practices for managing Bemisia tabaci and associated viral diseases. Crop Protection. 20, 801-812.

Hogenhout, S.A., Ammar, E.D., Whitfield, A.E. and Redinbaugh, M.G. (2008). Insect Vector Interactions with Persistently Transmitted Viruses. Annual Review of Phytopathology. 46, 327-59.

Holt, J., Colvin, J. and Muniyappa, V. (1999). Identifying control strategies for tomato leaf curl virus disease using an epidemiological model. Journal of Applied Ecology. 36, 625-633.

Hurelbrink, R.L., Marlow, G.A. and Ross, J.R. (1993). Role of public and private sectors in horticulture development, Uva Province Diversified Agriculture Research Project, Peradeniya, Sri Lanka.

Ikeda, H. (1996). Protected horticulture in Japan in comparison with several other countries. Farming Japan. 44, 20-28.

Jones, J.B., Jones, J.P., Stall, R.E. and Zitter, T.A. (2008). Compendium of tomato diseases. APS Press, St. Paul, Minnesota. p. 73.

Khalimi, K. and Suprapta, D.N. (2011). Induction of plant resistance against soybean stunt virus using some formulations of Pseudomonas aeruginosa. Journal of ISSAAS. 17(1), 98-105.

Khan, M.A., Mirza, J.H. and Ahmed, S. (1998). Relationships of environmental conditions conducive to cotton leaf curl virus disease development. Pakistan Journal of Phytopathology. 10, 5-8.

Lapidot, M. and Friedmann, M. (2002). Breeding for resistance to whitefly-transmitted geminiviruses. Annals of Applied Biology. 140, 109-127.

Lodhi, M.A., Ye, G., Weeden, N.F. and Reisch, B.I. (1994). Simple and efficient method for DNA extraction from grapevine cultivars, Vitis species and Ampelopsis. Plant Molecular Biology Reporter. 12(1), 6-13.

Mapa, R.B., Somasiri, S. and Dassanayake, A.R. (2010). Soil of the Dry Zone of Sri Lanka: Morphology, Characterization and Classification. Soil Science Society of Sri Lanka. 7, 86-87. 
Mehta, P., Waxman, J.A., Nakhla, M.K. and Maxwell, D.P. (1994). Transmission of tomato leaf curl geminiviruses by Bemisia tabaci (Homoptera: Alyrodidae). Journal of Economic Entomology. 87, 1291-1297.

Palumbo, J.C., Horowitz, A.R. and Prabhaker, N. (2001). Insecticidal control and resistance management for Bemisia tabaci. Crop Protection. 20, 739-765.

Parvin, A. (2002). Effect of condition of growing seedling and sowing time on prevalence of TYLCV and its impact on growth and yield of tomato. Unpublished MS Thesis. Department of Plant Pathology, BSMRAU, Gazipur. p. 99.

Paul, S.K. (2002). Management of TYLCV in respect to growth and yield of tomato using net house grown seedlings and insecticidal spray. Unpublished MS Thesis. Department of Plant Pathology, BSMRAU, Gazipur. p. 107.

Pautasso, M., Doring, T.F., Garbelotto, M., Pellis, L. and Jeger, M.J. (2012). Impacts of climate change on plant diseases-opinions and trends. European Journal of Plant Pathology. doi: 10.1007/s10658-012-9936-1.

Punyawardana, B.V.R. (2008). Evolution of climatic zoning in Sri Lanka. In: Agroclimatological Zones and Rainfall Pattern in Sri Lanka (in Sinhala medium). Published by Department of Agriculture, Sri Lanka. pp. 44-113.

Rahman, A.H.M A., Akanda, A.M. and Ashraful Alam, A.K.M. (2006). Relationship of Whitefly Population Build up with the Spread of TYLCV on Eight Tomato Varieties. Journal of Agriculture and Rural Development. 4(1\&2), 67-74.

Ramappa, H.K., Muniyappa, V. and Colvin, J. (1998). The contribution of tomato and alternative host plants to tomato leaf curl virus inoculum pressure in different areas of south India. Annals of Applied Biology. 133, 187-198.

Samarakoon, S.A.M.C., Balasuriya, A., Rajapaksha, R.G.A.S. and Wickramarachchi, W.A.R.T. (2012). Molecular Detection and Partial Characterization of Tomato Yellow Leaf Curl Virus in Sri Lanka. Pakistan Journal of Biological Sciences. 15, 863-870.

Seevers, P.M., Daly, J.M. and Catedral, F. (1971). The role of peroxidase isozymes in resistance to wheat stem rust disease. Plant Physiology. 48, 353-360.

Sheng, X.F. and Huang, W.Y. (2001). Physiological characteristics of strain NBT of silicate bacterium. Acta Pedologica Sinica. 38(4), 569-574.

Ssekyewa, C., Van Damme, P.L. and Hofte, M. (2007). Relationship between Tomato yellow leaf curl viruses and the whitefly vector. Communications in Agricultural and Applied Biological Sciences. 72(4), 1029-1048.

Sultana, N.A. ( 2001). An investigation to some aspects of TYLCV and TPVV infecting tomato. Unpublished MS Thesis. Department of Plant Pathology, BSMRAU, Gazipur. p. 90.

Swezey, S.L., Goldman, P., Bryer, J. and Nieto, D. (2006). Six-year comparison between organic, IPM and conventional cotton production systems in the Northern San Joaquin Valley, California. Renewable Agriculture and Food Systems. 22(1), 30-40. 
Ullman, D.E., Meideros, R., Campbell, L.R., Whitfield, A.E., Sherwood, J.L. and German, T.L. (2002). Thrips as vectors of tospoviruses. Advances in Botanical Research. 36, 113-140.

van Loon, L.C. (1997). Induced resistance in plant and the role of pathogenesis-related protein. European Journal of Plant Pathology. 103, 753-765.

Whitfield, A.E., Ullman, D.E. and German, T.L. (2005). Tospovirus - Thrips Interactions. Annual Review of Phytopathology. 43, 459-489. 